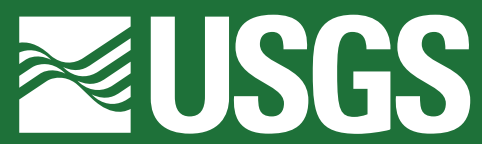

Prepared in cooperation with the Bureau of Reclamation

\title{
Potential Depletion of Surface Water in the Colorado River and Agricultural Drains by Groundwater Pumping in the Parker-Palo Verde-Cibola Area, Arizona and California
}

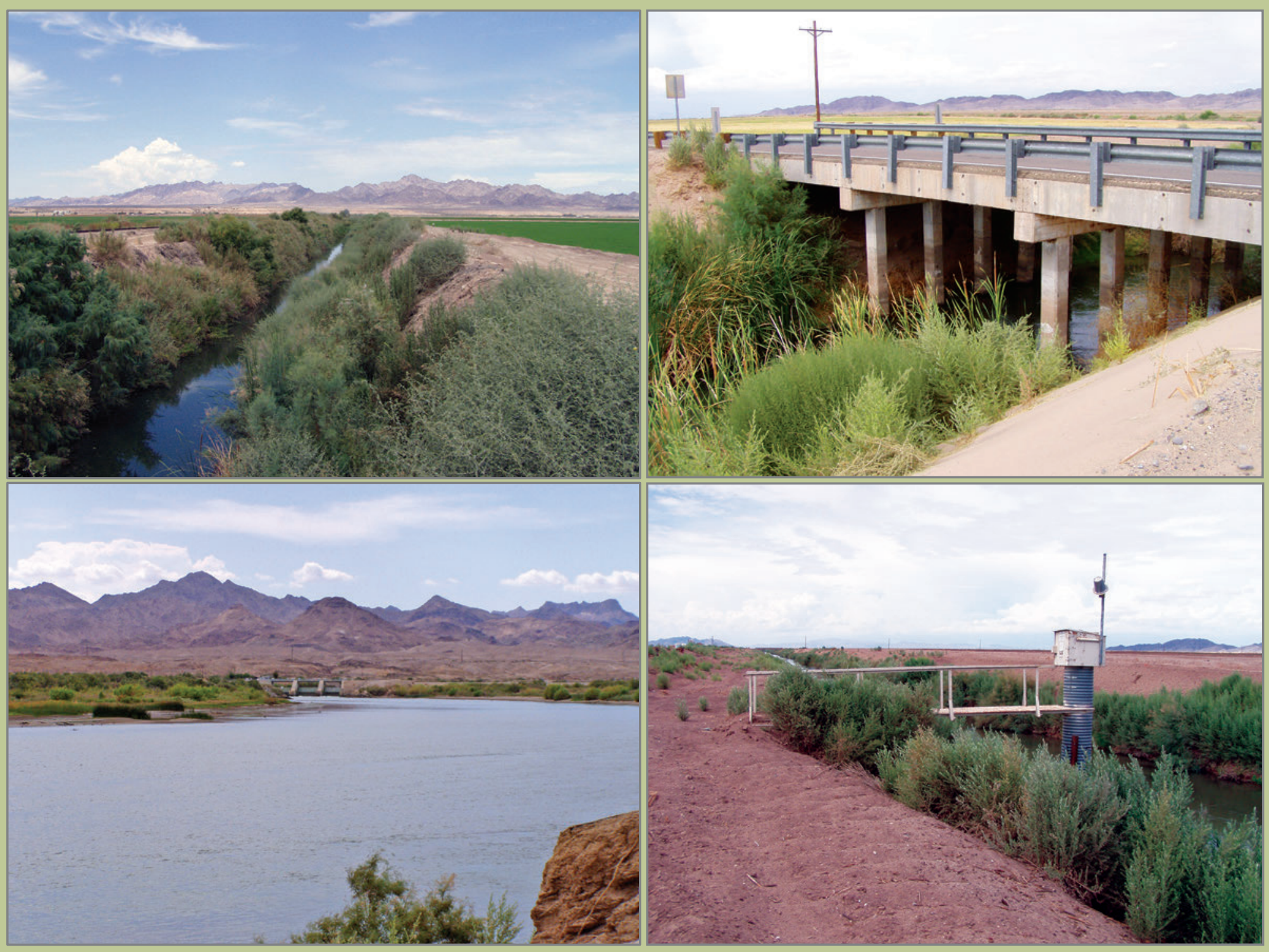

Scientific Investigations Report 2013-5134 


\section{FRONT COVER}

Photographs showing the Colorado River and agricultural drains in the study area. Clockwise from upper left: drain along the west side of the flood plain in Palo Verde Valley; highway bridge over a drain in Parker Valley; U.S. Geological Survey streamflow-gaging station in a drain at the lower end of Parker Valley; Colorado River looking northwest towards Palo Verde Dam. Photographs by Sandra J. Owen-Joyce, July 2007. 


\section{Potential Depletion of Surface Water in the Colorado River and Agricultural Drains by Groundwater Pumping in the Parker-Palo Verde-Cibola Area, Arizona and California}

By Stanley A. Leake, Sandra J. Owen-Joyce, and Julian A. Heilman

Prepared in cooperation with the Bureau of Reclamation

Scientific Investigations Report 2013-5134 


\section{U.S. Department of the Interior SALLY JEWELL, Secretary}

\section{U.S. Geological Survey Suzette M. Kimball, Acting Director}

\section{U.S. Geological Survey, Reston, Virginia: 2013}

For product and ordering information: World Wide Web: http://www.usgs.gov/pubprod Telephone: 1-888-ASK-USGS

For more information on the USGS—-the Federal source for science about the Earth, its natural and living resources, natural hazards, and the environment: World Wide Web: http://www.usgs.gov Telephone: 1-888-ASK-USGS

Any use of trade, firm, or product names is for descriptive purposes only and does not imply endorsement by the U.S. Government.

Although this information product, for the most part, is in the public domain, it also may contain copyrighted materials as noted in the text. Permission to reproduce copyrighted items must be secured from the copyright owner.

Suggested citation:

Leake, S.A., Owen-Joyce, S.J., Heilman, J.A., 2013, Potential depletion of surface water in the Colorado River and agricultural drains by groundwater pumping in the Parker-Palo Verde-Cibola area, Arizona and California: U.S. Geological Survey Scientific Investigations Report 2013-5134, 13 p. 


\section{Contents}

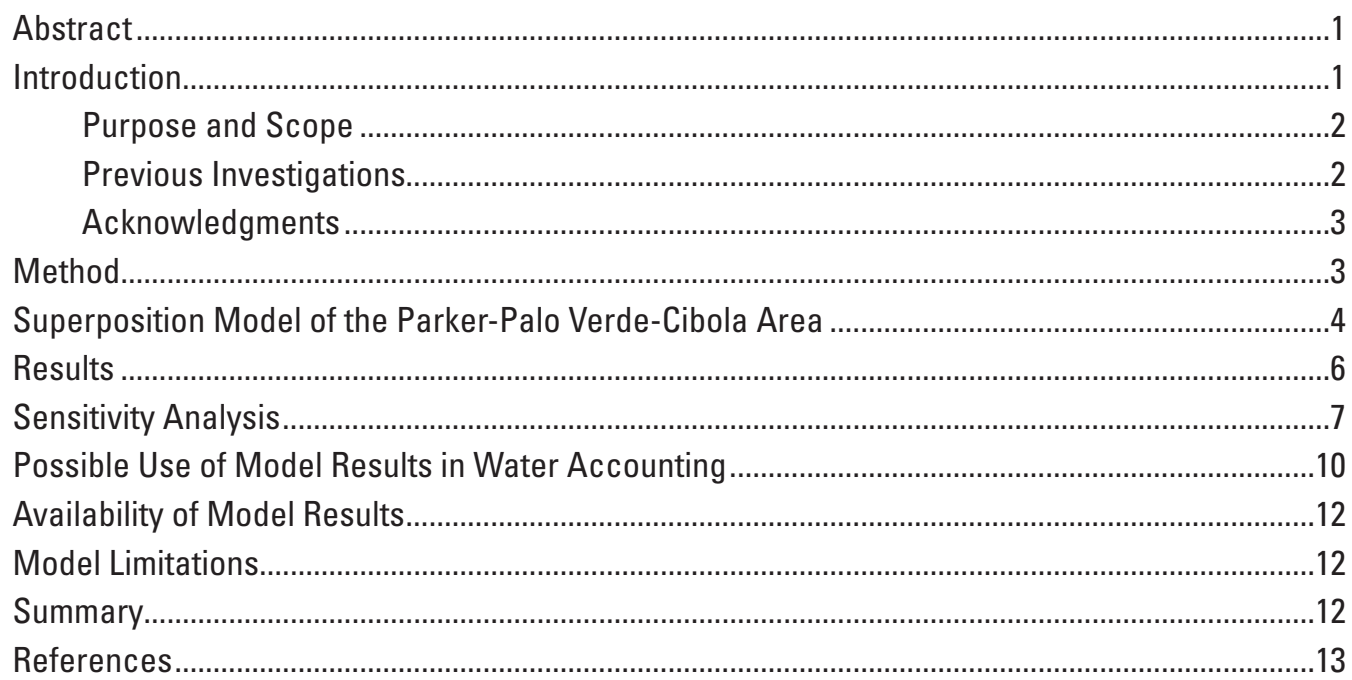

\section{Figures}

1. Map showing the river aquifer in the study area .....................................................................

2. Map showing central part of study area with model boundary conditions ...............................5

3. Schematic cross section showing vertical geometry of the three-layer superposition model ....6

4. Graph showing log-normal distribution of transmissivity from aquifer tests ...........................7

5. Map showing simulated depletion for pumping in model layer 1 ..............................................8

6. Graphs showing sensitivity of model results to transmissivity.................................................11 


\section{Conversion Factors}

\begin{tabular}{|c|c|c|}
\hline Multiply & By & To obtain \\
\hline & Length & \\
\hline \multirow[t]{2}{*}{ foot $(\mathrm{ft})$} & 0.3048 & meter $(\mathrm{m})$ \\
\hline & Flow rate & \\
\hline cubic foot per day $\left(\mathrm{ft}^{3} / \mathrm{d}\right)$ & 0.02832 & cubic meter per day $\left(\mathrm{m}^{3} / \mathrm{d}\right)$ \\
\hline gallon per minute (gal/min) & 0.06309 & liter per second (L/s) \\
\hline \multicolumn{3}{|c|}{ Hydraulic conductivity } \\
\hline \multirow[t]{2}{*}{ foot per day (ft/d) } & 0.3048 & meter per day (m/d) \\
\hline & Transmissivity* & \\
\hline \multirow[t]{2}{*}{ foot squared per day $\left(\mathrm{ft}^{2} / \mathrm{d}\right)$} & 0.09290 & meter squared per day $\left(\mathrm{m}^{2} / \mathrm{d}\right)$ \\
\hline & Conductance per unit length** & \\
\hline foot squared per day per foot $\left[\left(\mathrm{ft}^{2} / \mathrm{d}\right) / \mathrm{ft}\right]$ & 0.3048 & $\begin{array}{l}\text { meter squared per day per meter } \\
{\left[\left(\mathrm{m}^{2} / \mathrm{d}\right) / \mathrm{m}\right]}\end{array}$ \\
\hline
\end{tabular}

Vertical coordinate information is referenced to the National Vertical Geodetic Datum of 1929 (NGVD 29).

Horizontal coordinate information is referenced to the North American Datum of 1927 (NAD 27).

Altitude, as used in this report, refers to distance above the vertical datum.

*Transmissivity: The standard unit for transmissivity is cubic foot per day per square foot times foot of aquifer thickness: $\left[\left(\mathrm{ft}^{3} / \mathrm{d}\right) / \mathrm{ft}^{2}\right] \mathrm{ft}$. In this report, the mathematically reduced form, foot squared per day ( $\left.\mathrm{ft}^{2} / \mathrm{d}\right)$, is used for convenience. **Conductance per unit length: The standard unit for conductance per unit length is square foot per day divided by length of surface-water feature, in feet: $\left(\mathrm{ft}^{2} / \mathrm{d}\right) / \mathrm{ft}$. In this report, the mathematically reduced form, foot per day (ft/d), is used for convenience. 


\title{
Potential Depletion of Surface Water in the Colorado River and Agricultural Drains by Groundwater Pumping in the Parker-Palo Verde-Cibola Area, Arizona and California
}

\author{
By Stanley A. Leake, Sandra J. Owen-Joyce, and Julian A. Heilman
}

\section{Abstract}

Water use along the lower Colorado River is allocated as "consumptive use," which is defined to be the amount of water diverted from the river minus the amount that returns to the river. Diversions of water from the river include surface water in canals and water removed from the river by pumping wells in the aquifer connected to the river. A complication in accounting for water pumped by wells occurs if the pumping depletes water in drains and reduces measured return flow in those drains. In that case, consumptive use of water pumped by the wells is accounted for in the reduction of measured return flow. A method is needed to understand where groundwater pumping will deplete water in the river and where it will deplete water in drains. To provide a basis for future accounting for pumped groundwater in the Parker-Palo Verde-Cibola area, a superposition model was constructed. The model consists of three layers of finitedifference cells that cover most of the aquifer in the study area. The model was run repeatedly with each run having a pumping well in a different model cell. The source of pumped water that is depletion of the river, expressed as a fraction of the pumping rate, was computed for all active cells in model layer 1, and maps were constructed to understand where groundwater pumping depletes the river and where it depletes drains. The model results indicate that if one or more drains exist between a pumping well location and the river, nearly all of the depletion will be from drains, and little or no depletion will come from the Colorado River. Results also show that if a well pumps on a side of the river with no drains in the immediate area, depletion will come from the Colorado River. Finally, if a well pumps between the river and drains that parallel the river, a fraction of the pumping will come from the river and the rest will come from the drains. Model results presented in this report may be considered in development or refinement of strategies for accounting for groundwater pumping in the river aquifer connected to the Colorado River in the study area.

\section{Introduction}

According to the "Law of the River," users within the lower Colorado River Basin states can divert water from the Colorado River only with a recognized entitlement. The Consolidated Decree of the United States Supreme Court in Arizona v. California, 547 U.S.150 (2006), requires the Secretary of the Interior, through the Bureau of Reclamation (Reclamation), to account for diversions and consumptive uses of Colorado River water and recognizes that diversion of water from the Colorado River can occur by both surface and underground pumping. The "river aquifer" is defined as the saturated groundwater system hydraulically connected to the Colorado River, including the flood-plain sediments, older alluvial sediments, and sediments in connected adjacent valleys (Wilson and Owen-Joyce, 1994). Groundwater in the river aquifer beneath the flood plain is considered to be Colorado River water, and water pumped from wells on the flood plain is presumed to be river water and is accounted for as Colorado River water. A method was developed by the U.S. Geological Survey (USGS) in cooperation with Reclamation to identify wells in the river aquifer outside of the flood plain of the lower Colorado River that yield water that will be replaced by water from the river (Wilson and Owen-Joyce, 1994; Owen-Joyce and others, 2000). This method was needed to identify which wells require an entitlement for diversion of water from the Colorado River and need to be included in accounting for consumptive use of Colorado River water as outlined in the Consolidated Decree. Wiele and others (2008) updated the method on the basis of conditions in 2007-2008.

The mainstream of the Colorado River includes the main channel and the reservoirs behind the dams. Mainstream water is defined as water drawn or diverted from the main channel, including reservoirs, wetlands, lakes, ponds, backwaters, and water pumped from wells within the boundary of the flood plain portion of the river aquifer. Flow in the river is controlled by dams and no longer naturally floods over the flood plain; however, the flood plain is artificially recharged by river water diverted at Headgate 
Rock and Palo Verde Dams that is applied to agricultural fields. In Parker and Palo Verde Valleys, essentially all water applied to irrigate agricultural fields on the flood plain is diverted from the river. Drainage ditches are another major surface-water feature connected to the aquifer. In this report, drainage ditches are referred to as "drains." Most of the irrigated areas along the lower Colorado River include one or more networks of drains that are incised into the water table for the purpose of removal of excess water applied for irrigation of crops. In addition to excess water from applied irrigation of river water, drains may include a minor amount of tributary water (water from precipitation and inflow from tributary valleys along the edges of the flood plain). Also, a portion of the water in some drains may be from direct seepage from the Colorado River, particularly where the level of a drain adjacent to the river is below the average stage of the river. Water captured in the drainage network returns to the Colorado River and is measured at streamflow-gaging stations. In areas where Reclamation uses that measured return flow to calculate consumptive use, it is accounted for in Decree accounting. Unused water from irrigation that flows in the subsurface to the river is considered unmeasured return flow and is estimated by Reclamation by applying a factor to the diversion to include in Decree accounting. Previous studies have shown that unmeasured groundwater return flow occurs in the area between the river and the nearest drainage ditch (Leake, 1984; Owen-Joyce, 1984). Water pumped from wells that intercept unmeasured return flow needs to be included in Decree accounting.

Water in the lower Colorado River is allocated between the States of Arizona, California, and Nevada on the basis of consumptive use, which is computed as diversions minus return flow. Diversions of water from the river can occur from direct use of surface water as well as from "underground pumping." Consumptive use of water pumped by wells that deplete flow only in drains is accounted for by the reduction in return flow caused by depletion. Some wells, however, may deplete flow only in the river, and others may deplete flow in the river and in drains. For wells that increase consumptive use by decreasing measured return flow in drains, also charging the pumping rate as a diversion would result in double accounting of consumptive use by the wells. In July 2008, Reclamation published a Federal register notice (Bureau of Reclamation, 2008) to create a rule to use the accounting-surface method to identify wells that need to be included in Decree accounting. Public comments indicated that water users along the lower Colorado River expressed interest in Federal water managers considering the possibility of double accounting of water use by wells on the flood plain. To further understand the possibility of double accounting of water use by pumping wells, Reclamation let a contract to determine the impact of wells on the flood plain on unmeasured return flow to the Colorado River in an area with drains. Reclamation also subsequently set up a hydrology group to explore methods of assessing where double accounting might occur along the Colorado River.
Group members include Reclamation and USGS staff. The initial study verified that the concern for double accounting was valid (Zhu and others, 2012), which initiated this study to use a superposition computer model to estimate the relative fractions of water in drains and water in the river as ultimate (steady-state) sources of water for potential pumping well locations in Palo Verde and Parker Valleys. Palo Verde and Parker Valleys have extensive systems of drains (fig. 1) to capture irrigation return flow and move it back to the river and lower the water table. The drainage systems have streamflow-gaging stations positioned to measure this return flow for accounting purposes to calculate consumptive use. Cibola Valley also has a network of drains but streamflow is not gaged; therefore, return flow from this valley is unmeasured.

\section{Purpose and Scope}

The purpose of this study is to compute relative ultimate depletion of surface-water features, including the Colorado River and drains. Depletion of water in canals and depletion or reduction in evapotranspiration by plants by groundwater pumping may be possible in some areas, but these effects of pumping are not quantified in this study. The area of interest is the river aquifer adjacent to the reach of the Colorado River that includes Parker, Palo Verde, and Cibola Valleys, and adjacent areas in California and Arizona as shown in figure 1. The scope of the report is to present an analysis of relative effects of pumping wells on surface water in the Colorado River and drains in the Parker, Palo Verde, and Cibola Valleys and adjacent parts of the river aquifer in California and Arizona. The effect considered is "ultimate" or "steady-state" depletion of surface water, when change in aquifer storage is no longer a significant source of pumped water. This report describes a method and application of that method to estimate the fraction of well pumping that represents ultimate depletion of the Colorado River in the study area (fig. 1).

\section{Previous Investigations}

Metzger and others (1973) presented results of an investigation of the hydrogeology of the study area. Their report remains as the primary source of information related to the groundwater in the study area. Tucci (1982) constructed a two-layer groundwater model of the Parker Valley for the U.S. Geological Survey Southwest Alluvial Basins Regional Aquifer-System Analysis project. Leake (1984) and OwenJoyce (1984) estimated unmeasured groundwater return flow to the Colorado River from applied irrigation in the Parker and Palo Verde-Cibola areas, respectively. Leake and others (2008) constructed a one-layer superposition groundwater model of the entire study area to estimate transient depletion of the Colorado River at a pumping time of 100 years for hypothetical pumping locations. 


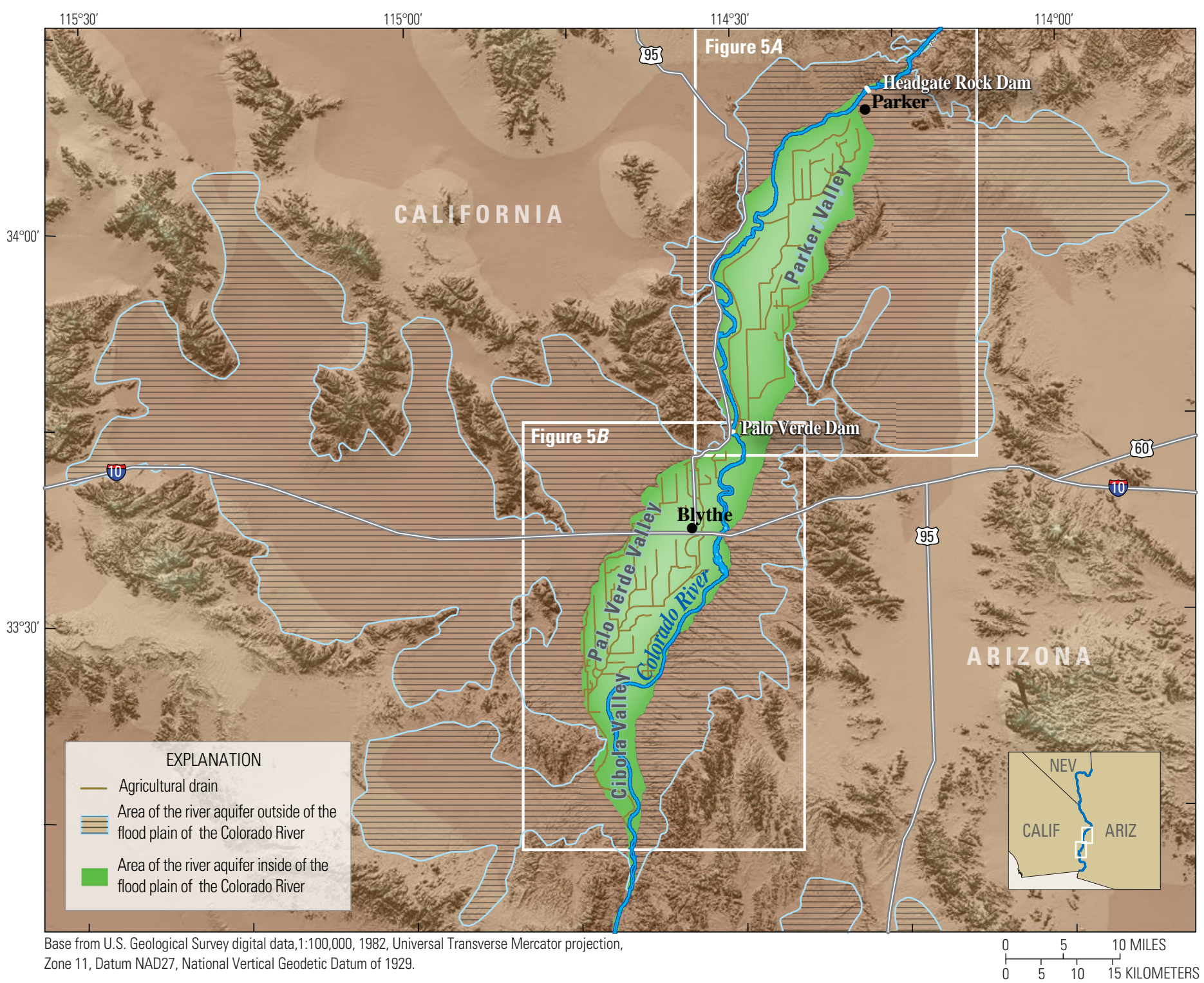

Figure 1. Map showing the river aquifer in the study area. Large rectangles show locations of separate detailed maps of model results for the Parker area (figure $5 A$ ) and the Palo Verde-Cibola area (figure $5 B$ ).

\section{Acknowledgments}

Construction of the groundwater model described in this report required preparation of a geographic information system (GIS) coverage of the drainage networks in Palo Verde and Parker Valleys. The authors are grateful to Roger Henning, Chief Hydrologist, Palo Verde Irrigation District; Grant Buma, Acting Director of Water Resources, Colorado River Indian Tribes; and Steve Belew, Bureau of Reclamation, for providing facility maps needed for this effort. Paul Matuska, Jeremy Dodds, William Greer, Kenneth Isakson, and William Bruninga of the Bureau of Reclamation provided insight on water-management needs for this study.

\section{Method}

When a well begins to pump, initially all water comes from storage in the aquifer. With time, drawdown from the well extends to areas of connected surface water and evapotranspiration areas and decreases outflow from the aquifer or increases inflow to the aquifer. The combination of all decreased outflow and increased inflow caused by pumping groundwater is called "capture" (Barlow and Leake, 2012, fig. 44). Pumping-induced reduced outflow to and increased inflow from streams and rivers is referred to as "streamflow depletion." In this report, the effects of decreased outflow to the river and drains and increased inflow from the 
river caused by groundwater pumping are referred to simply as "depletion." With continued pumping, depletion will become a more important source of water to the pumping well. If a well pumps for long enough, a new steady-state condition will be reached in which all of the water being pumped will be from depletion. "Ultimate depletion" is the term used in this report to describe depletion of surface water in the river and drains when aquifer storage no longer is a source of pumped water. For details on the timing of depletion by pumping wells, see Barlow and Leake (2012).

Ultimate depletion of surface-water features in the area could be computed with a steady-state groundwater flow model of the river aquifer. Such a model, however, does not exist and it is beyond the scope of this study to create a calibrated groundwater flow model. The approach taken instead was to create a relatively simple steady-state superposition groundwater model of the area, using MODFLOW-2005 (Harbaugh, 2005), referred to as "MODFLOW" in this report.

A superposition model uses an initial flat water surface with head set to zero in the aquifer and in connected surface-water features and with recharge set to zero. With the addition of a stress such as a pumping well, changes in groundwater flow in the aquifer and from surface-water boundaries are simulated directly. With a steady-state superposition model, ultimate depletion of individual surface-water features from groundwater pumping at any real or hypothetical well location can be computed. Reilly and others (1987) presented methods of applying the principle of superposition in groundwater models. They indicated that a constraint on use of the superposition approach is that the system responds linearly to imposed stress such as pumping groundwater. In the study area, response to pumping is likely to be linear because pumping from the river aquifer is not likely to cause large changes in saturated thickness and transmissivity, nor will it cause surface-water features to dry up or become disconnected from the aquifer. Another advantage of linear response is that depletion can be expressed as a fraction of the pumping rate for any given well location. That fraction can be used to compute the actual depletion for any actual pumping rate within the range of linear response. For example, if the ultimate depletion fraction for the Colorado River for a particular pumping location were 0.4 , then ultimate depletion of the river at a pumping rate of $10 \mathrm{gal} / \mathrm{min}$ would be $4 \mathrm{gal} / \mathrm{min}$ and at a pumping rate of $200 \mathrm{gal} / \mathrm{min}$ would be $80 \mathrm{gal} / \mathrm{min}$. For a transient analysis of possible depletion of the Colorado River in this area, Leake and others (2008) used a transient superposition model. Other examples of use of superposition models to compute depletion from groundwater pumping include Leake and others (2005) and Halford and Plume (2011). For additional discussions on superposition models, see Leake (2011) and Barlow and Leake (2012, p. 65).

One consideration in using the superposition-modeling approach to evaluate effects of groundwater pumping on the Colorado River is that results are limited to determination of net effects of pumping on surface-water flow. A superposition model cannot be used to determine whether the effect is to reduce agricultural return flow to the river, reduce natural tributary groundwater discharge to the river, or induce inflow of surface water from the river to the aquifer. In most of the study area, however, groundwater from applied irrigation discharges to the river (Leake, 1984; Owen-Joyce, 1984) and tributary inflow from natural groundwater recharge is a small component of the water budget. Furthermore, nearly all tributary groundwater inflow would discharge to drains in Parker and Palo Verde Valleys, rather than to the river. In applying the superpositionmodeling approach in the study area, a reasonable assumption is that effects of groundwater pumping on the river represent a reduction of agricultural return flow to the river in areas adjacent to irrigated land. In areas not adjacent to irrigated land, computed depletion can be assumed to represent either induced infiltration from the river, or reduction in the down-valley groundwater flow that would naturally discharge to the river at the lower end of the study area.

\section{Superposition Model of the Parker- Palo Verde-Cibola Area}

The superposition model consists of a flat-lying grid of finite-difference cells that spans nearly all of the river aquifer as defined by Wilson and Owen-Joyce (1994). The northern and southern extents of the model grid are shown on figure 2. Western and eastern extents of the grid are also the western and eastern limits of the river aquifer shown on figure 1. A similar horizontal domain was used by Leake and others (2008) for a transient superposition model that was used to estimate timing of depletion of the Colorado River as a function of pumping location. General characteristics of the steady-state superposition model developed for this study are as follows:

1. Internal head-dependent flow boundaries represented include the Colorado River and drains (figs. 2, 3). The Colorado River and segments of drains below the lowermost streamflow-gaging station were represented with the MODFLOW River Package (Harbaugh, 2005). Segments of drains above the lowermost streamflow-gaging station were represented with the MODFLOW General-Head Boundary Package (Harbaugh, 2005). The drains represented are shown on figures 1 and 2. The ungaged drains in Cibola Valley were not included in the model. The model did not include head-dependent flow boundaries for areas where groundwater is used by phreatophytes (deep-rooted plants that obtain water from a permanent groundwater-supply).

2. The lateral edges of the river aquifer (figs. 1,2) and the base of the aquifer were represented as no-flow boundaries. 


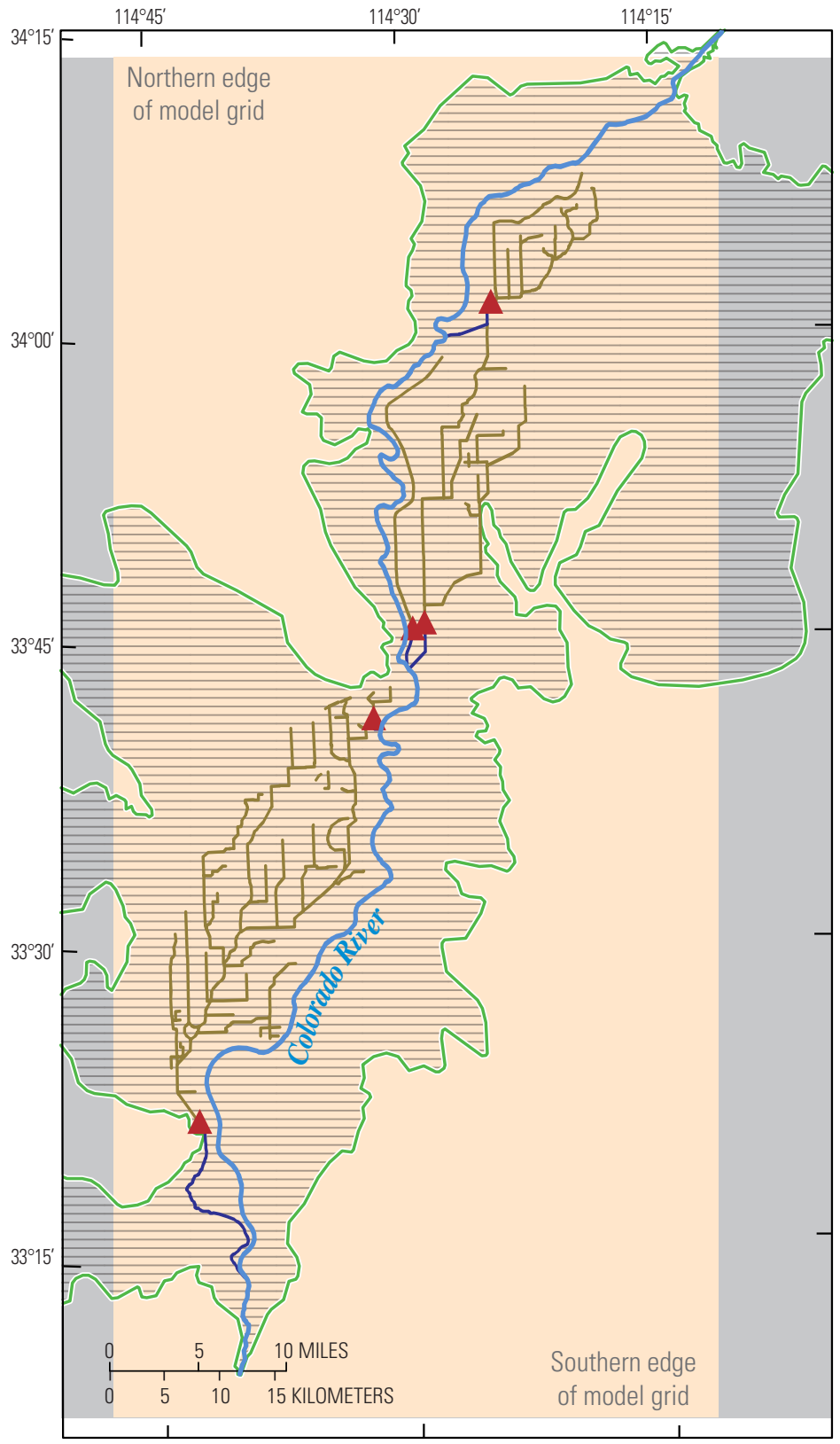

EXPLANATION

- Gage at which return flow in drainage ditch is measured

$\rightleftharpoons$ River aquifer, with outer edge simulated as a no-flow boundary

Colorado River, simulated with the River Package

Agricultural drain above return-flow measuring point, simulated with the General-Head Boundary Package

Agricultural drain below return-flow measuring point, simulated with the River Package

Area where grid spacing along rows is 660 feet

Area where grid spacing along rows is larger than 660 feet

Figure 2. Map showing central part of study area with model boundary conditions including locations of the Colorado River and agricultural drains. Color bands in the background indicate regions where grid spacing along rows is 660 feet and where grid spacing along rows is larger than 660 feet.
3. For any given simulation, a single well was represented as a specified-flow boundary using the MODFLOW Well Package (Harbaugh, 2005). Because the system responds linearly to pumping stress, any pumping rate can be used to determine ultimate depletion of the river and drains. For this study, a pumping rate of 10,000 $\mathrm{ft}^{3} / \mathrm{d}$ was used and simulated values of depletion of the river and drains were divided by that rate to get depletion as a fraction of pumping rate.

4. Initial head at every active model cell and boundary head for the River Package and General-Head Boundary Package were set at zero feet above datum.

5. The product of aquifer thickness and horizontal hydraulic conductivity is transmissivity, an important parameter in models of aquifers dominated by horizontal flow. With the model setup used, results will be nearly the same for different combinations of horizontal hydraulic conductivity and aquifer thickness that result in the same transmissivity. For the superposition model of the study area, an overall uniform transmissivity of $26,200 \mathrm{ft}^{2} / \mathrm{d}$ was used. That value corresponds to a probability of 0.5 on the lognormal distribution function for transmissivity from aquifer tests along a portion of the lower Colorado River that includes the study area (fig. 4; Leake and others, 2008). To get the desired transmissivity, total aquifer thickness was set at $400 \mathrm{ft}$ and horizontal hydraulic conductivity was set to $65.5 \mathrm{ft} / \mathrm{d}$ (fig. 3). Vertical hydraulic conductivity was assumed to be 0.1 of the horizontal hydraulic conductivity, or $6.55 \mathrm{ft} / \mathrm{d}$. That value results in a ratio of vertical to horizontal hydraulic conductivity, $K_{v} / K_{h}$, of 0.1 , which is within reason for alluvial aquifers that include coarse sediments with some discontinuous fine-grained interbeds.

6. Bed conductance per foot length of surface-water feature was set to $200 \mathrm{ft} / \mathrm{d}$ for the Colorado River and $20 \mathrm{ft} / \mathrm{d}$ for drains. Actual values of this parameter are unknown and are grid-size dependent in a finitedifference model. Values were selected to represent both the river and drains as not having any bed sediments that restrict movement of water between the river or drains and the underlying aquifer. Drains must be well-connected to the underlying aquifer to function properly in removing excess water and keeping the water table below the root zones of crops. The difference in bed conductance per foot length between drains and the river reflect the fact that the Colorado River is much wider than the drains. Within model cells that contain a drain or the river, the length of the drain or river within the cell is multiplied by the bed conductance per foot length to get the total bed conductance for that cell. 
7. The model grid includes 309 rows, 339 columns, and 3 layers of finite-difference cells. Rows are oriented in an east-west direction, and columns are oriented in a north-south direction. The grid spacing along columns is a uniform 1,320 ft. Each row of grid cells, therefore, has a width of 1,320 ft in the north-south direction. Grid spacing along rows is variable, with a band of uniform spacing of $660 \mathrm{ft}$ encompassing the Colorado River and drains (fig. 2). To the west of that band in California and to the east in Arizona, cells become increasingly wider, with maximum widths of 19,235 ft and 13,077 ft on the western and eastern sides of the model, respectively. The variable spacing allowed for more detail in the area of river and drains, and less detail in adjacent side valleys that are part of the river aquifer.

8. Three model layers with thicknesses of 40,120, and $240 \mathrm{ft}$ were used to simulate the upper, middle, and lower parts of the system, respectively (fig. 3). Use of multiple model layers allowed evaluation of effects of depth of pumping on relative depletion of the Colorado River and drains.

9. The MODFLOW Layer-Property Flow Package (Harbaugh, 2005) was used to specify input data and set up the finite-difference equations to be solved in MODFLOW. In that package, layer type for all three model layers was specified as "confined," resulting in use of transmissivity that does not change from pumping the added well. In actuality, a pumping well creates a cone of depression in the water table that reduces transmissivity; however, in a highly transmissive aquifer with connected surface water at the surface, drawdown of the water table usually is minimal and transmissivity can be assumed to be constant in analyses of effects of groundwater pumping.
To understand sources of water to wells at any location in the study area, the model was run repeatedly, with each run having a well in a different location (model cell). For each model run, information saved included model layer, row, and column of the pumped well; Universal Transverse Mercator Zone 11 coordinates of the pumped well; fraction of the pumping rate that is depletion of the river and drain segments below the lowermost streamflow-gaging station; and simulation mass-balance error, expressed in cubic feet per day. If model mass-balance error is small, depletion fractions for the drains above the lowermost streamflow-gaging station can be computed as 1.0 minus the depletion value saved for the river and drain segments below the lowermost streamflow-gaging station.

\section{Results}

Using an automated program, sequential model runs were made to simulate the effects of pumping a well in each cell in layer 1 and in each cell in layer 3, for a total of 93,098 model runs. In making model runs to compute depletion of surface-water features, it is important that the magnitude of the overall mass-balance error of the model is much smaller than the pumping rate of the added well (Leake and others, 2010). If the model mass-balance error is large, then depletion cannot be calculated with confidence. The average and maximum absolute mass-balance errors for 46,549 model runs in which cells in layer 1 were pumped were 0.39 and $2.29 \mathrm{ft}^{3} / \mathrm{d}$, respectively. The fact that those numbers are small relative to the pumping rate of $10,000 \mathrm{ft}^{3} / \mathrm{d}$ means that mass-balance error has not significantly affected the calculation of depletion of the river and that depletion of drains can be computed as 1.0 minus the computed depletion of the river.
Figure 3. Schematic cross section showing vertical geometry of the three-layer superposition model, aquifer properties used for the basecase transmissivity, and conductance of the river and drains.

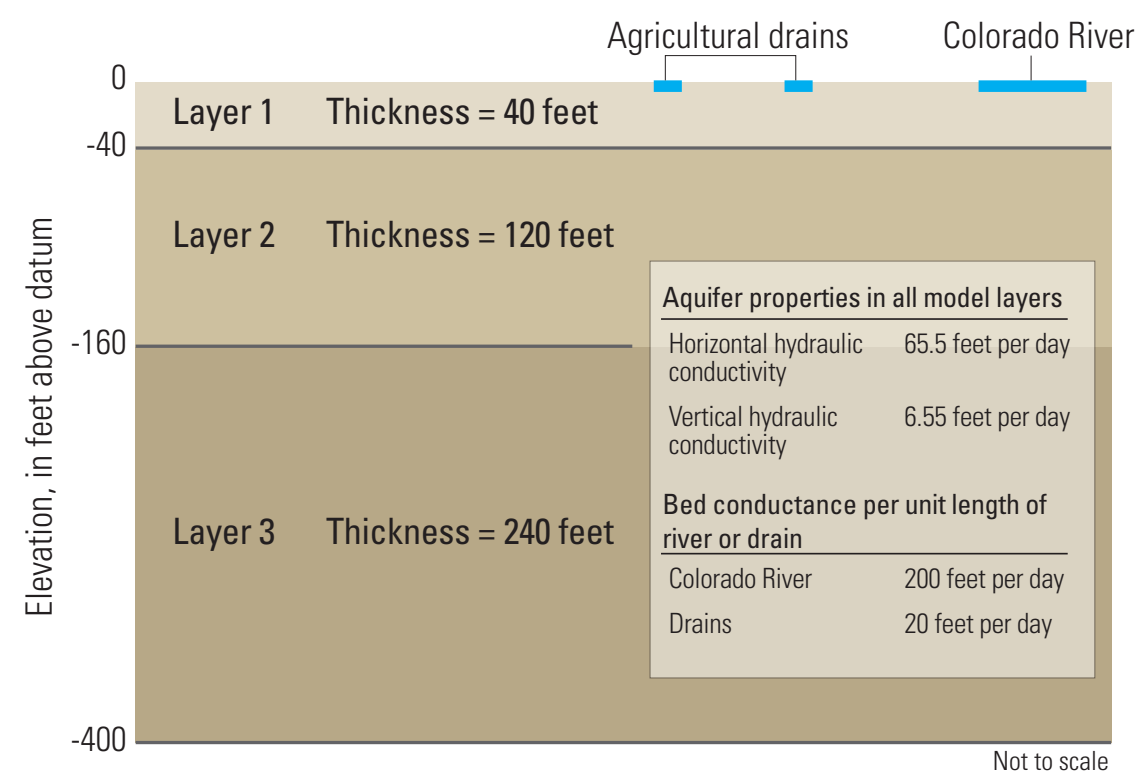


Results for pumping in layer 1 in terms of the fraction of the pumping rate that is depletion of the Colorado River are shown in figures $5 A$ and $5 B$ for portions of the northern and southern parts of the study area, respectively. Some general results are as follows:

1. In areas between a drain and the river, the source of pumped water ranges from nearly all from the river at the location of the river, to nearly none from the river at the location of the closest drain to the river. The 0.5 fraction, where half of the water comes from depletion of the river and half comes from depletion of drains, is near the midpoint of the interval between the river and drains.

2. In areas without drains, such as west of the river in Parker Valley (fig. 5A), east of the river in Palo Verde Valley, and in and around Cibola Valley (fig. 5B), nearly all depletion is from the river.

3. In areas in which drains exist between the pumped location and the river, nearly all pumped water is from depletion of drains (fig. 5).

Results for pumping in layer 3 are nearly identical to results for pumping in layer 1 for most of the study area. For about 99 percent of the lateral pumping locations simulated, the absolute difference in depletion fraction from pumping in layer 1 versus pumping in layer 3 is less than 0.05 . The other 1 percent of pumping locations is along the Colorado River and along drain segments closest to the river. The following section includes further discussion of pumping in layer 1 versus layer
3 for a specific location. Digital files with depletion fractions for pumping in layers 1 and 3 are available in the groundwatermodel archive for this study, as described in a later section.

Ignoring groundwater evapotranspiration by phreatophytes means that some depletion of evapotranspiration will instead be attributed to depletion of the river or drains in the model. In highly transmissive aquifers with surface-water features and adjacent narrow bands of phreatophytes, nearly all depletion will be from the surface-water feature. Aquifer head in these phreatophyte areas is held at or near the level of the adjacent surface water, which limits drawdown and depletion of evapotranspiration. Significant depletion of evapotranspiration is most likely to occur when pumping is within or adjacent to larger areas of dense phreatophytes. In the model of the study area, effects of ignoring depletion of evapotranspiration are most likely to be significant only in the lower end of Cibola Valley. The model results in that area show that nearly the entire source of pumped water is depletion of the Colorado River. In reality, some fraction of the pumped water may come from depletion of evapotranspiration. Additional work would be required to quantify depletion of evapotranspiration as a source of water to pumped wells.

\section{Sensitivity Analysis}

To understand the effects of certain model parameters on computed depletion of the Colorado River, a limited sensitivity analysis was carried out for model cells along section $A-A^{\prime}$
Figure 4. Graph showing log-normal distribution of transmissivity from aquifer tests along the lower Colorado River, with lines showing the locations of low and high transmissivity values ( 5 and 95 percent, respectively, of the distribution less than or equal to these values). Figure modified from Leake and others (2008).

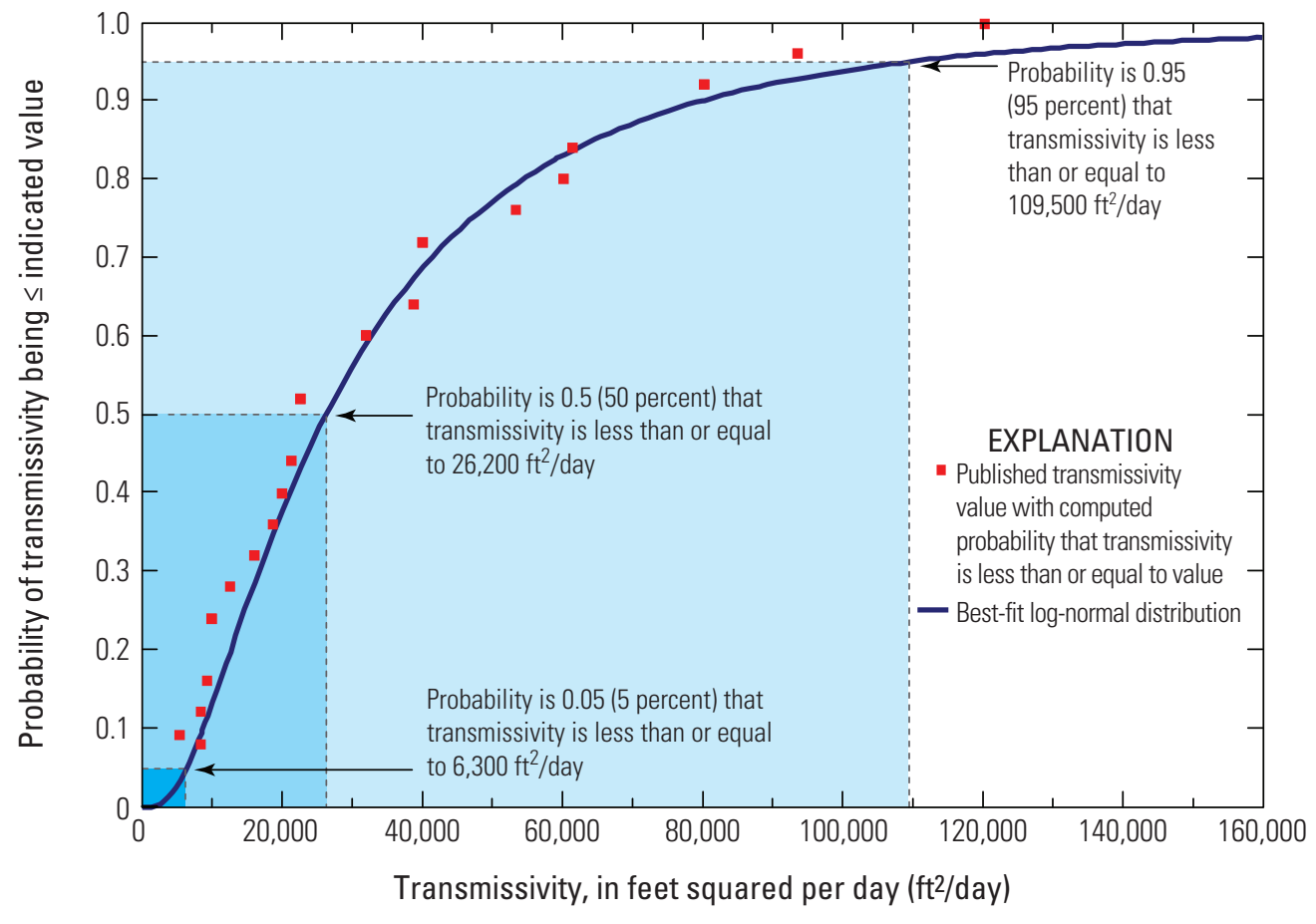




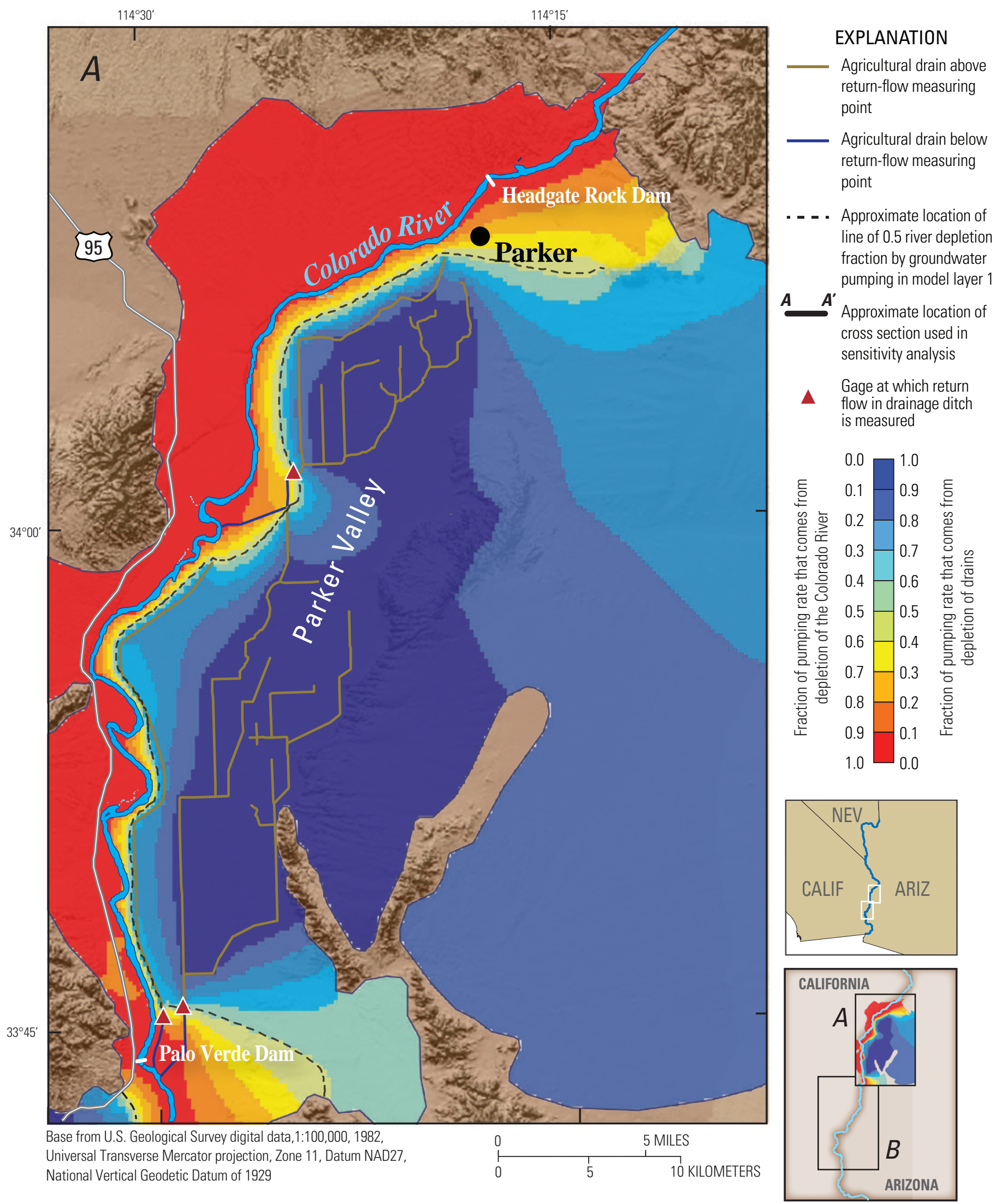

Figure 5. Map showing simulated depletion for pumping in model layer 1 for portions of the northern, $A$, and southern, $B$, parts of the study area. 


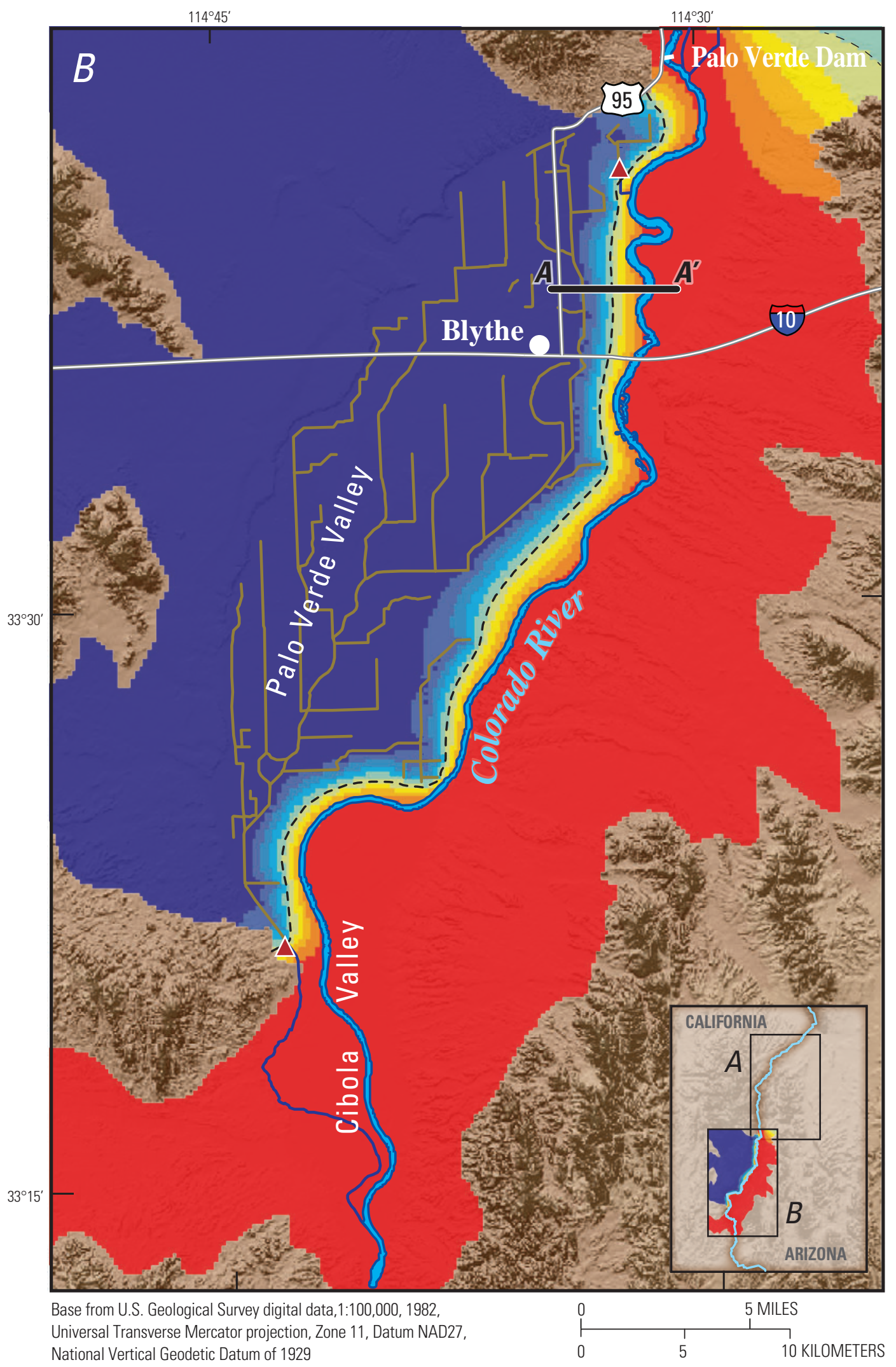

Figure 5.-Continued. 
shown on figure $5 B$. Simulations using properties specified in the section "Superposition Model of the Parker-Palo VerdeCibola Area" with pumping in layer 1 are considered the base case, and simulations with different properties show how results vary from the results of the base case. Properties and conditions tested include (1) pumping in layer 1 versus layer 3, (2) lower and higher transmissivity, (3) lower ratio of vertical to horizontal hydraulic conductivity anistrophy, and (4) higher values of river and drain conductance.

For evaluation of effects of transmissivity on computed depletion fractions, "low" and "high" transmissivity values were selected using probabilities of 0.05 and 0.95 , respectively, on the log-normal distribution for transmissivity (fig. 4). Using those probabilities, the low transmissivity is $6,300 \mathrm{ft}^{2} / \mathrm{d}$, and the high transmissivity is $109,500 \mathrm{ft}^{2} / \mathrm{d}$. Results along section $A-A$ ' for pumping in layer 1 using the base-case, low, and high transmissivity values are shown in figure $6 \mathrm{~A}$. The point of 0.5 depletion with a high transmissivity is about $894 \mathrm{ft}$ west (towards the drains) of that point for the base case. The point of 0.5 depletion with a low transmissivity is about $263 \mathrm{ft}$ east (towards the river) of that point for the base case. The depletion fraction at the location of the river is nearly the same for all three transmissivity values tested, but at the location of the drains, higher and lower transmissivity results in more and less river depletion, respectively. In general, higher transmissivity allows drawdown to propagate further to deplete more water in the network of drains. That effect is less pronounced for pumping locations near the river, where nearly all pumped water is supplied by depletion of the river, regardless of the magnitude of transmissivity.

Differences in depletion fractions from pumping in layer 1 and layer 3 using a transmissivity of 26,200 ft²/d and a ratio of vertical to horizontal hydraulic conductivity of 0.1 can be seen by comparing the thick blue curve and the red curve in figure $6 B$. The curves are nearly identical except at the locations of the river and drains. Using a lower ratio of vertical to horizontal hydraulic conductivity, the point along section $A-A$ ' at which half of pumped water comes from river depletion is nearly the same for pumping in layers 1 and 3 ; however, use of the lower ratio with pumping in layer 3 tends to increase the depletion of the river at pumping locations near the drains and increase depletion of drains at pumping locations near the river.

In the base-case simulations, conductance per foot length of surface-water feature was set to $200 \mathrm{ft} / \mathrm{d}$ for the Colorado River and $20 \mathrm{ft} / \mathrm{d}$ for drains, resulting in a ratio of 10:1 for river conductance to drain conductance. In one sensitivity analysis, the conductance per foot length of the Colorado River was increased to $1,600 \mathrm{ft} / \mathrm{d}$ and the conductance per foot length of drains was held at $20 \mathrm{ft} / \mathrm{d}$, resulting in a ratio of 80:1 for river conductance to drain conductance. Computed river depletion for pumping locations along section $A-A$ ' were nearly identical to values computed in the base case with a 10:1 ratio (fig. 6C). The reason for this insensitivity is that the original conductance was already high enough so that the river was well connected to the aquifer. Pumping-induced drawdown in a cell with the river is near zero because there is almost no head loss across the riverbed sediments. With increased conductance, the drawdown in a cell with a river might be less by a small amount, but is still near zero. Increasing the conductance in this range, therefore, does not change simulation results by much. In another sensitivity analysis, the river conductance per foot length was set at the original value of $200 \mathrm{ft} / \mathrm{d}$ and the drain conductance per foot length was set at $160 \mathrm{ft} / \mathrm{d}$. With those values, river depletion at the location of the drain was reduced to near zero, and the position of the line of 0.5 river depletion along section $A-A^{\prime}$ was moved $425 \mathrm{ft}$ to the east (fig. $6 C$ ). That scenario is not considered to be reasonable, however, because river and drain conductance should differ at least by an order of magnitude because of differences in widths of these two features. It is possible that simulation results would be more sensitive to the ratio of river conductance to drain conductance if both values were in a smaller range in which more head loss occurs across bed sediments. That condition is not considered realistic for surface-water features in the study area because both the river and drains are thought to be well connected to the aquifer without the presence of extensive low-permeability bed sediments that restrict the movement of water between the aquifer and the surface-water feature.

General conclusions of the sensitivity analyses are that the position of the 0.5 depletion line can be moderately sensitive to transmissivity, but that position was not shown to be sensitive to depth of pumping and ratio of vertical to horizontal hydraulic conductivity. Depletion between the river and the drain was not sensitive to an increase in riverbed conductance. More comprehensive sensitivity analyses could be carried out by generating new sets of 0.5 depletion lines for a larger subset of pumping locations between the river and the closest drain using conditions and properties that vary from the base case.

\section{Possible Use of Model Results in Water Accounting}

The model results illustrate a number of key points that may be useful in developing strategies in accounting for the use of water in the lower Colorado River. First, if one or more drains exist between a pumping well location and the river, nearly all of the depletion will be from drains, and little or no depletion will come from the Colorado River. The effect of the pumping will be to reduce measured return flow to the river. Second, if a well pumps on a side of the river with no drains in the immediate area, depletion will come from the Colorado River. Third, if a well pumps between the river and one or more drains that parallel the river, a fraction of the pumping will come from the river and the rest will come from the drains. The relative amounts of the well pumping rate coming from the river and drains is mostly dependent on which surface-water features are closest to the pumping well. For any well, the part of the pumping rate that is depletion of 


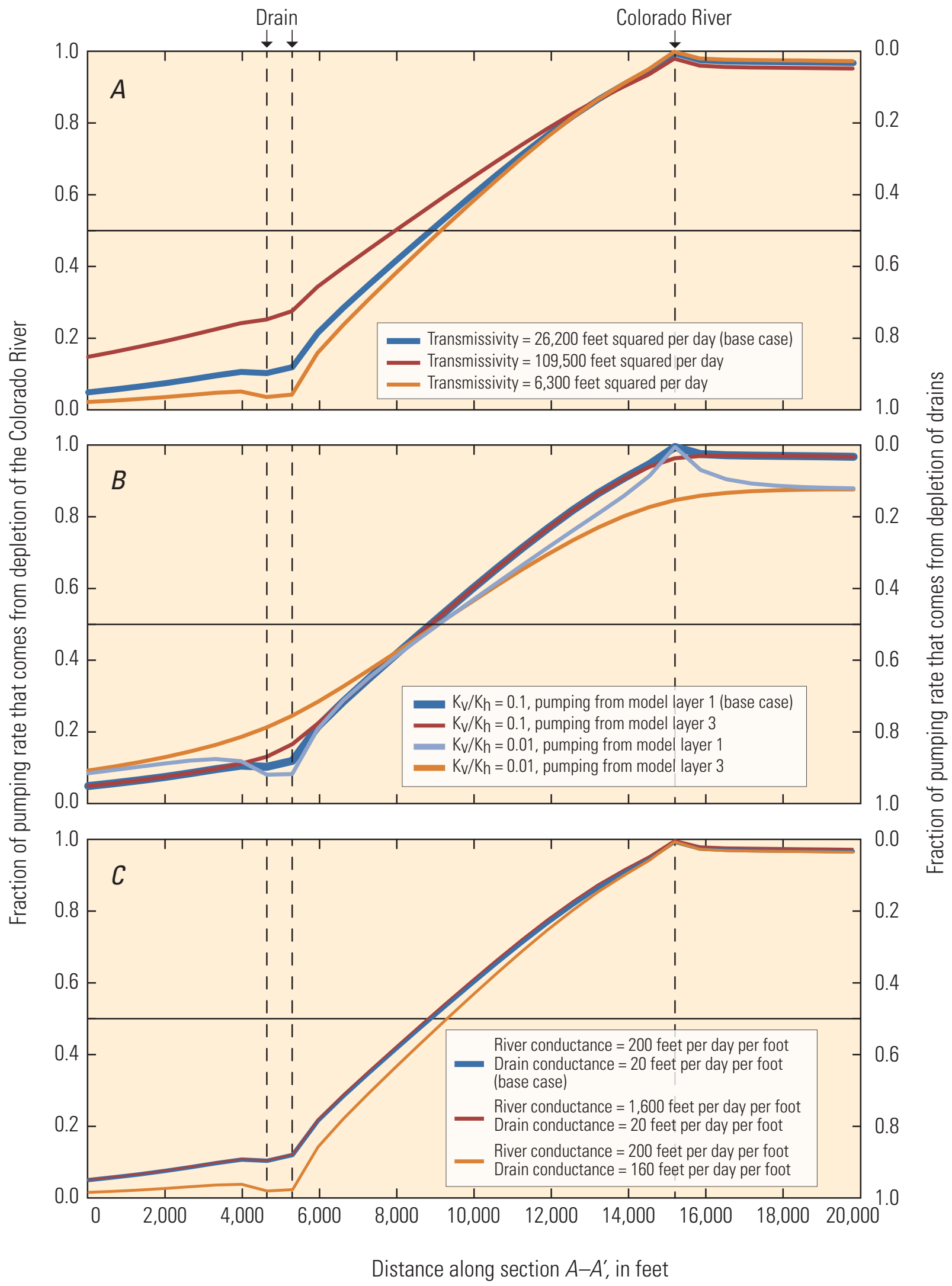

Figure 6. Graphs showing sensitivity of model results to $A$, transmissivity, $B$, anisotropy ratio and depth of pumping, and $C$, river and drain conductance for a cross section $A-A^{\prime}$, traversing model cells with drains and the Colorado River in Palo Verde Valley. Location of the cross section is shown on figure $5 B$. 
the river can be considered a diversion of water from the river. Depletion of water in drains above the return-flow measuring point, on the other hand, reduces the return flow and thereby increases the consumptive use of water for the drained area.

\section{Availability of Model Results}

Results of model runs to estimate depletion of the Colorado River and drains are available in two ASCII files. One of the files contains results for pumping each of 46,549 active model cells in layer 1 and the other for pumping the same number of active model cells in layer 3. Each file contains the following seven data items (fields), separated by a commas:

- Field 1- layer number of model cell with pumping well

- Field 2- row number of model cell with pumping well

- Field 3-column number of model cell with pumping well

- Field 4- Universal Transverse Mercator Zone 11 easting, in meters, of center of model cell with pumping well

- Field 5- Universal Transverse Mercator Zone 11 northing, in meters, of center of model cell with pumping well

- Field 6-Computed depletion of the Colorado River, expressed as a fraction of the pumping rate

- Field 7- Model mass-balance error, in cubic feet per day

The fraction of the pumping rate that is depletion of the Colorado River (field 6), ranges from about 0 to 1.0. For any model run, the fraction of the pumping rate that is depletion of drains can be computed by subtracting the value of field 6 from 1.0. Model data sets and files containing model results described here may be requested from the Arizona Water Science Center, U.S. Geological Survey, Tucson, Arizona.

\section{Model Limitations}

As discussed previously, the groundwater superposition model described in this report was designed to compute ultimate (steady-state) relative depletion of the Colorado River and agricultural drains by pumping wells within the study area (fig. 1). Application of the model for purposes other than evaluation of relative depletion of the river and drains by pumping wells is an inappropriate use of the model.

\section{Summary}

Water in the lower Colorado River is allocated on the basis of consumptive use, computed as diversions of water from the river minus the amount that returns to the river. In addition to direct diversions of surface water from the river, pumping by wells in the aquifer connected to the river also can be considered a diversion of water from the river. A complication in accounting for water pumped by wells occurs if the pumping depletes water in drains and reduces measured return flow in those drains. In that case, consumptive use of water pumped by the wells is accounted for in the reduction of measured return flow. A method is needed to understand where groundwater pumping will deplete water in the river and where it will deplete water in drains.

A steady-state superposition model was constructed to compute relative depletion of the Colorado River and drains for the Parker-Palo Verde-Cibola area. The model consists of 309 rows, 339 columns, and 3 layers of finite-difference cells. Surface-water features represented include the river and drains in Parker and Palo Verde Valleys. A transmissivity value of $26,200 \mathrm{ft}^{2} / \mathrm{d}$ was selected on the basis of a log-normal distribution of transmissivity values from aquifer tests along a portion of the lower Colorado River. The model was run repeatedly, each run with a pumping well in a different model cell in layer 1 , for a total of 46,549 model runs. That same number of model runs was repeated for pumping in model cells in layer 3. Fractions of the pumping rate that is depletion of the river for all model cell locations in layer 1 were mapped to understand where groundwater pumping depletes the river, and where it depletes drains.

The model results indicate that if one or more drains exist between a pumping well location and the river, nearly all of the depletion will be from drains, and little or no depletion will come from the Colorado River. Results also show that if a well pumps on a side of the river with no drains in the immediate area, depletion will come from the Colorado River. Finally, if a well pumps between the river and drains that parallel the river, a fraction of the pumping will come from the river and the rest will come from the drains. A key factor in which feature is depleted the most - drains or the river-is the location of the well relative to each of these features.

A sensitivity analysis for a location in Palo Verde Valley indicated that the position of the point where river depletion is 0.5 of the pumping rate is moderately sensitive to the transmissivity value used. The position of that point, however, was less sensitive to depth of pumping, the ratio of vertical to horizontal hydraulic conductivity, and conductance of surfacewater features. 


\section{References}

Barlow, P.M., and Leake, S.A., 2012, Streamflow depletion by wells-Understanding and managing the effects of groundwater pumping on streamflow: U.S. Geological Survey Circular 1376, $84 \mathrm{p}$.

Bureau of Reclamation, 2008, Regulating the use of lower Colorado River water without an entitlement; Proposed Rule: Federal Register, v. 75, no. 137, Wednesday, July 16, 2008, Proposed Rules, p. 40916. (Also available at http:// www.gpo.gov/fdsys/pkg/FR-2008-07-16/html/E8-16001. htm)

Halford, K.J., and Plume, R.W., 2011, Potential effects of groundwater pumping on water levels, phreatophytes, and spring discharges in Spring and Snake Valleys, White Pine County, Nevada, and adjacent areas in Nevada and Utah: U.S. Geological Survey Scientific Investigations Report 20115032, $52 \mathrm{p}$.

Harbaugh, A.W., 2005, MODFLOW-2005, The U.S. Geological Survey modular ground-water model-The groundwater flow process: U.S. Geological Survey Techniques and Methods 6-A16, variously paginated.

Leake, S.A., 1984, A method for estimating ground-water return flow to the Colorado River in the Parker area, Arizona and California: U.S. Geological Survey WaterResources Investigations Report 84-4229, 31 p.

Leake, S.A., 2011, Capture-Rates and directions of groundwater flow don't matter!: Ground Water, v. 49, no. 4, p. 456-458.

Leake, S.A., Greer, W., Watt, D., and Weghorst, P., 2008, Use of superposition models to simulate possible depletion of Colorado River water by ground-water withdrawal: U.S. Geological Survey Scientific Investigations Report 20085189, 25 p.

Leake, S.A., Hoffmann, J.P., and Dickinson, J.E., 2005, Numerical ground-water change model of the $\mathrm{C}$ aquifer and effects of ground-water withdrawals on stream depletion in selected reaches of Clear Creek, Chevelon Creek, and the Little Colorado River, northeastern Arizona: U.S. Geological Survey Scientific Investigations Report 2005-5277, 29 p.

Leake, S.A., Reeves, H.W., and Dickinson, J.E., 2010, A new capture fraction method to map how pumpage affects surface water flow: Ground Water, v. 48, no. 5, p. 690-700.
Metzger, D.G., Loeltz, O.J., and Irelan, B., 1973, Geohydrology of the Parker-Blythe-Cibola area, Arizona and California: U.S. Geological Survey Professional Paper 486-G, 130 p.

Owen-Joyce, S.J., 1984, A method for estimating groundwater return flow to the Colorado River in the Palo VerdeCibola area, California and Arizona: U.S. Geological Survey Water-Resources Investigations Report 84-4236, $48 \mathrm{p}$.

Owen-Joyce, S.J., Wilson, R.P., Carpenter, M.C., and Fink, J.B., 2000, Method to identify wells that yield water that will be replaced by water from the Colorado River downstream from Laguna Dam in Arizona and California: U.S. Geological Survey Water-Resources Investigations Report 00-4085, 3 plates, 31 p.

Reilly, T.E., Franke, O.L., and Bennett, G.D., 1987, The principle of superposition and its application in groundwater hydraulics: U.S. Geological Survey Techniques of Water-Resources Investigations, book 3, chap. B6, 28 p.

U.S. Supreme Court, 2006, State of Arizona, plaintiff v. State of California, et al., defendants: U.S. Supreme Court Consolidated Decree-March 27, 2006, no. 8, original, $34 \mathrm{p}$.

Tucci, P., 1982, Use of a three-dimensional model for the analysis of the ground-water flow system in Parker Valley, Arizona and California: U.S. Geological Survey Open-File Report 82-1006, 54 p.

Wiele, S.M., Leake, S.A., Owen-Joyce, S.J., and McGuire, E.H., 2009, Update of the accounting surface along the lower Colorado River: U.S. Geological Survey Scientific Investigations Report 2008-5113, version 1.1, 16 p., 3 plates in pocket. (Also available at http://pubs.usgs.gov/ sir/2008/5113/.)

Wilson, R.P., and Owen-Joyce, S.J., 1994, Method to identify wells that yield water that will be replaced by Colorado River water in Arizona, California, Nevada, and Utah: U.S. Geological Survey Water-Resources Investigations Report 94-40.

Zhu, J., Pohlmann, K.F. and Healey, J., 2012, Significance of groundwater divide in water accounting and return flow calculation for lower Colorado River aquifers: Desert Research Institute duplicated report, $50 \mathrm{p}$. 
$\frac{\mathbb{2}}{\mathrm{S}}$

ลี่ 